\title{
Teacher Perceptions of Critical Thinking among Students and Its Influence on Higher Education $^{1}$
}

\author{
Ammar Hussein Yasir, Asst.Prof. Bushra Saadoon Mohammed Alnoori, Ph.D \\ University of Baghdad, Iraq
}

DOI: 10.37648/ijrst.v10i04.002

Received: 10 $0^{\text {th }}$ September, 2020; Accepted: 04 ${ }^{\text {th }}$ October, 2020; Published: 10 ${ }^{\text {th }}$ October, 2020

\begin{abstract}
A few decades ago, taxonomies included the concept of critical thinking. Critical thinking is a difficult process that necessitates advanced cognitive abilities in information processing. Teachers' judgments of students' critical thinking have an impact on their classroom behavior. Teachers believe they are teaching critical thinking to their pupils and that critical thinking will give the intellectual stimulation that will allow critical thinking, according to research. The ability of students to articulate ideas and concepts in their own terms was seen as proof of critical thinking. The capacity to analyze logically and solve problems through novel techniques, on the other hand, is a valuable asset. The process through which a student gains understanding of the content delivered is not an indication of the student's higher-level cognitive ability. Teachers did not appear to comprehend the needs for instilling critical thinking in children. Teachers may believe they are encouraging critical thinking in the classroom, but they are really focusing on subject matter comprehension.
\end{abstract}

\section{SECTION ONE}

\subsection{Introduction}

One of the current study questions in education is whether students can learn to think critically on their own or if the skill must be explicitly taught as part of the curriculum. (Sternberg and Williams, 2002, p. 62) noted that students may not need to be taught critical thinking as a natural process carried by everyone. But Duron, Limbach and Waugh (2006) appealed that thinking is a natural process, but when left to itself, can often be biased, distorted, incomplete, uninformed and potentially prejudiced; excellence in thought must be refined. Black (2005) also found that students are able to improve their thinking skills if they were taught how to think.
Furthermore, Nickerson (1994) noted that students need to be taught how to think more efficiently, that is more critically, logically, and creatively. For example, teachers could provide students with the criteria for judging information and taught the terms and strategies used for critical thinking (Black, 2005, p. 22). Therefore, although students have a natural ability to think critically, it is important for teachers to guide them in order to refine their skills.

Critical thinking was first highlighted by Benjamin Bloom's taxonomy a few decades ago (Duron, Limbach, \& Waugh, 2006; Lauer, 2005). It was perceived that a higher level of cognitive ability concerning critical thinking was a feature in the analysis, synthesis, and evaluation levels even though

${ }^{1}$ How to cite the article: Yasir A.H., Alnoori B.S.M., Teacher Perceptions of Critical Thinking among Students and Its Influence on Higher Education, IJRST, Oct-Dec 2020, Vol 10, Issue 4, 7-19, DOI: http://doi.org/10.37648/ijrst.v10i04.002 
lower levels of cognitive ability that is knowledge, comprehension, and application only involved remembering, relating and applying information respectively (Duron et al. 2006, p. 77). Duron et al. described critical thinkers as those who are able to analyse and evaluate information. They noted that critical thinkers are those who are able to raise vital questions and problems, verbalize them clearly, gather and assess relevant information, use, abstract ideas, think open-mindedly, and communicate successfully with others. (p. 160)

However, Riddell (2007) noted that as critical thinking specialists have done, critical thinking should not be defined but rather explained by its components and features, stages, and traits. According to prior research, critical thinking can also be defined as a reflection, identification, and assessment of assumptions, investigation, interpretation, and analysis, and reasoning and judgment, all while taking context into account. As a result, critical thinking is a difficult process that requires advanced cognitive processing abilities.

The way in which information is directed and conveyed to students may affect the students' capability to think critically. Duron et al. (2006) pointed out that the lecture format of learning a prevalent approach in higher education may not encourage active learning of critical thinking on the part of students. For students to think critically and learn actively, teachers must part with the perception that students cannot learn unless a teacher covers it. However, many teachers still notice that student need to be taught before they can learn (Choy, 2003, p. 120). Teachers should also be flexible and show students that there is often more than one solution to a problem (Black, 2005, p. 76). Consequently, it is important to consider the influence of teacher perceptions of how students learn.

\subsection{The Concept of Critical Thinking}

Depending on the context, the notion of critical thinking has been defined variably in the literature. Critical thinking encompasses all cognitive processes and methods, as well as attitudes, that are engaged in decision-making, problem-solving, inquiry, or higherorder thinking in general. It also involves deciding rationally what to or what not to believe (Norris, 1985 as cited in Yildirim and Ozkahraman, 2011). As said by (Elder \& Paul, 1994 as cited in Morale, 2011) critical thinking is best understood as the ability of thinkers to take charge of their thinking. Harris and Hodges (1995) cited in (ibid) defines critical thinking as a process of arriving at a judgement about the value or impact of a text by examining its quality. Critical thinking is conceptualized as a process of examining and evaluating ideas, events and arguments in their contexts. It includes questioning assumptions and classifying biases.

\subsection{The Motives for Critical Thinking in Education Today}

Critical thinking and problem solving were once considered the domain of brilliant kids, but nowadays, teaching pupils how to think rather than what to think should be a priority for all students. This is because the global economy necessitates citizens who are capable of evaluating conflicting claims, comparing evidence, and making sound decisions. Further to that, the solutions to international problems, such as global warming, require highly developed critical thinking and problem-solving abilities who can directly take actions. In social studies classrooms, this means students can analyse different sources of information and facts concerning political and social issues (Salam \& Hew, 2010). It is vital for kids to learn how to think critically in order to be successful in their life, particularly in today's globalized society (Gallavan \& Kottler, 2012; Morrison \& Walsh, 2001; Kagan, 2005). Being able to make reasoned decisions and appreciated judgments can be the difference between success and failure in the work world. Apparently, in the 21 st century where governments and industries are looking for growing their economies, critical thinking in education becomes the most valuable skill so as to produce experienced graduates for regional and globe competitiveness, and hence schools are charged responsible to respond to these and other societal needs. To do so, schools must re-think their attention and develop and implement curricula that will produce the necessary human capital to recognise viable solutions for these needs (Shah, 2010). It has been claimed by Thompson (2011) that, teaching for critical thinking should then be a learning goal for all teachers across all disciplines and levels. Chun (2010) also supports this argument that, so as to meet the demands of a dynamic global society, teaching for 
critical thinking competence should include a philosophical change in focus from learning to thinking, drill to practice, outcome to process and subject isolation to integration. Based on this logic, I was intrigued and excited about my practicum school's integration of all social science disciplines into a single curriculum called social science. Students master abilities from history, geography, English, civics, and religion all at once in this course. Furthermore, the school assigns a single teacher to lead the class from start to finish. This, in my opinion, is just as vital as the instructor getting to know her or his students and vice versa. Under such circumstances, learning process become consistence and organized. This is not a good practice because, sometimes, it confuses learners as it is known that, we are not all the same in handling issues, and likely as in teaching. Teaching is an art, and every teacher has a unique style of teaching, so this frequent change of teachers is sometimes confusing to leaners, and it may bring discrepancies in curriculum practice, and lastly may affect the students learning performance. Furthermore, Beyer (1995) sees the teaching of critical thinking as important to the very state of our nation. People must be able to think critically in order to make appropriate decisions regarding personal and civic matters, he claims, in order to live successfully in a democracy. Students who learn to think critically will be able to use sound thinking as a guidance in their daily lives.

\subsection{Theoretical Perspective on Critical Thinking Teaching}

The literature clearly shows that several scholars have researched how students learn and under what conditions effective teaching and learning occurs, and many hypotheses on how individuals learn have been created over time. (Boyanton, 2015). Such leaning theories existing in the literatures include: Behaviourism (classical conditioning and operant conditions theories); the social cognitive learning theories and the constructivism theory. However, this paper centres itself on constructivism theory as a relevant theoretical perspective to critical thinking teaching as a central topic of the discussion. Under this crucial section of the paper, which serves as a lens for educators in their efforts to improve critical thinking teaching both inside and outside the classroom, I believe it is worthwhile to begin the discussion by providing a brief definition of the term; the origins of Constructivism Theoretical Perspective; and its implications in education and classroom practices.

\subsection{A Conceptual Understanding of Constructivism}

Constructivism is a learning theory that explains how people learn what they know. For constructivists, learning is a process of knowledge creation that involves higher order active thinking skills such as comparing, interpreting, synthesizing, evaluating, and then accommodating new knowledge in relation to prior knowledge. (Boyanton, 2015). The impression behind this theoretical viewpoint is that problemsolving is at the heart of learning, thinking, and development. Constructivists like Bruner, Piaget, Ausebel, claim that, people construct their own understanding when they are involved in problemsolving and discovery inquiry in that, the consequences of their actions are a reflection of the past and new experience.

On the word of (Piaget 1952 as cited in Boyanton, 2015) reveal that, new meaning is always constructed upon prior knowledge through comparing, analysing and connecting the new with what one already knows. Hence for constructivists, learning is thus an active process that requires a change in the learner. This is explicitly achieved through the activities the learner engages in, including the consequences of those activities, and through reflection. As explained above, it is clearly understood that, the underlying philosophy of constructive theory is different with the underlying philosophy of some other theories, especially theories of behaviourism and information processing (cognitivism). This is because, while these theories considered the reality of the universe to be independent of the mind and external to the learner and learning, constructivism theory holds that students are the subject of teaching, and thus teachers should provide a conducive learning environment for students to discover and interact with themselves, the teacher, the subject matter, and learning materials. This means that in an instructional process, students remain passive consumers of information, ensuring that they receive accurate information from the teacher. In theory, constructivism stresses student initiative and interaction in the classroom because this is how 
students build their cognitive capacities. "Educational activities are designed and implemented in classrooms for teaching and learning. Activities engage pupils and prevent them from being passive learners. Activities help to create interest in a subject and make learning meaningful, ( Bushra Alnoori, 2019, p 1222). The focus on exploratory, cooperative, active learning enhanced through interactive learning tasks should be the goal of every teacher in the modern world in promotion of critical thinking skills among learners.

\subsection{Origin of Constructivism}

Any theory has a foundation and history, and constructivism learning theory is no exception. Its beginnings are mostly addressed from philosophical and psychological perspectives. Constructivism's philosophical roots may be traced back to Socrates and his Socratic method of teaching and classroom evaluation, which focuses on questioning and answering as a tool for encouraging critical thinking among students. According to Dewey (1916; 1938), the idea of progressive education has a lot of contributions on how education institutions can reshape their structures to go in hand with social-cultural changes. Although Dewey emphasizes that, teachers need to engage students in reflective thinking in order to produce a sense of community and participation within the classroom, new perspectives are developed, shared and critiqued. It was not until the 1950's when. Educators began to teach critical thinking skills in the classroom as an integral component of the curriculum (Bataineh, \& Alazzi, 2009).

In the perspective of psychology, Piaget, and Vygotsky are the first psychologists who contributed a lot to the development of constructivism thought and its application in classes which geared to promotion of students' learning and development (Jia, 2010). In fact, according to the available literatures, Piaget is taken as the portent of modern constructivism. However, during 70s and 80s in 20th century, Russia excellent psychologist Vygotsky discovered the base for the creation of modern constructivism where he argues that learning is a social construction and thus new knowledge is advanced through discussion and negotiations (Boyanton, 2015). Going further, for Vygotsky, the language of instruction is therefore vital for promotion of interpersonal communication among students themselves, the learning media and with the teacher. This is important because teachers' feedback to student's question will enable their comprehension on the taught concepts. Further to that, as a student interacts with other classmates, the concepts is consolidated and kept in the long-term memory for future retrieval.

\subsection{The Relevancy of Constructivism Theory to Critical Thinking Teaching}

The constructivism learning theory is the most relevant with regard to high educational demand in today's global societies, which are characterized by international economic competitiveness, technology, and information advancements, implying that an individual's competence level is the most important determinant of entry into a pull quality workforce. This has prompted several countries throughout the world to modify their educational curricula and teaching techniques in order to educate students to graduate with 21 st-century abilities. For example, there was the knowledge promotion reform Norway in (2006) which presented new curriculum for basic education aiming at improving the quality of lower secondary education (OECD, 2011). From the year 2005 in Tanzania, there were the curriculum reform in education which stressed pedagogical shift from content-based teaching to competence-based teaching. The aim was to encourage quality education by preparing graduates who are competent and well-educated with the necessary skills and knowledge to help them in their future living while working with others and bring development in their own society and nation at large.

\section{SECTION TWO}

\subsection{Present Study}

Drawing on the concept that critical thinking is social in nature (Vaske, 2001, p. 78), this sort of thinking does not happen lest there is sharing and interacting with others; therefore, critical thinking entails reflection after that, communication with others. The current study focuses on instructors' perceptions of their students' critical thinking and how this may influence how they teach and if they are able to develop this type of thinking in their pupils. 
The main research questions behind this study were:

- What are teacher's perceptions of critical thinking?

- What are their perceptions of students' ability to think critically?

- What are their perceptions of the role they have to play when integrating critical thinking in their lessons?

The investigation was carried out by means of a qualitative approach, using a sample of lecturers from institutions of higher learning in Iraq.

\subsection{Method}

The interpretive method was inspired by the research questions. Individuals construct personal meaning when they grapple with the environment around them to make it meaningful in this method (Radnor, 2002, p. 99), implying a need for an in-depth and insightful analysis of the data obtained. The aim is to view reality as being socially constructed where the activities of individuals are being continuously interpreted and reinterpreted to give a meaningful explanation to behaviours usually within a particular context (Holliday, 2002; Radnor, 2002). The meanings obtained in this manner are actually conceptualized, temporary knowledge (Greene, 2000). The responses were considered according to themes interpreted from the data.

\subsection{Design and Procedure}

The data for this inquiry was gathered via a questionnaire. A questionnaire containing a total of eight questions was given to the 17 respondents. The questions were designed to elicit their thoughts on critical thinking. The questionnaire was semistructured to allow respondents to respond in the most efficient manner feasible. The questionnaire's themes were initially derived from a survey of relevant literature. An initial list of fifteen questions was revised until just eight questions remained. (See Table 1 for the questions on the questionnaire).

The examination of the responses to the questionnaire was done using the process of topic ordering, a term used by Radnor (2002) to describe the process of preparing qualitative data for analysis. The transcripts were inductively analysed using this method. Through repeated readings of the data, the primary categories were able to emerge from the data. The transcripts were read several times in order to categorize the important points that arose. Another researcher double-checked the final categorization of the data for consistency.

\section{Table 1}

List of Questions on the Questionnaire on Teacher's Perceptions of Critical Thinking

\section{From your viewpoint, what is critical thinking?}

2. What role, in your opinion, does critical thinking play in your classroom?

3. Do you think that critical thinking happens in your classroom when you are teaching your students? If so, how do you know?

4. How do you think you could bring about critical thinking among students? Specifically, what are some things you do or could do to get your students to think critically?

5. What are the problems faced by students when you are trying to teach them critical thinking? If so identify them.

6. Do you think your lessons are enjoyable to students? Why and why not?

7. Do you think you need to give all the information to your students in order for them to learn your subject? Why and why not?

8. Do you think you would be able to implement critical thinking into your lessons if you were required to do so? Why and why not? 


\subsection{Participants}

The sample taken for this study is made up of teachers learning in institutions of higher learning in Iraq who volunteered to take part in the study. These teachers come from various disciplines. Because the study was grounded in the interpretive approach, total objectivity and neutrality in the data analysis process cannot be claimed. We approached teachers' value-laden responses from our own understanding and definition of critical thinking. We admit our own subjectivity, which we bring about by respecting the worlds and sensitivities of the participants in the research context (Denzin \& Lincoln, 1994; Holliday, 2002). Even if the findings are only directly applicable to the Iraqi population, they may give knowledge that is useful to other people in comparable situations.

\subsection{Results}

Analysis of the prominent points of the data resulted in a total of 6 categories of teachers' observation of critical thinking. These categories will be used to answer the three research questions (RQ).

\section{Research Question 1:}

\section{What are Teachers' Perceptions of Critical Thinking?}

The results obtained from the analysis of two of the categories were used to answer RQ 1. The two categories used were the respondents' perception of critical thinking from their definition of critical thinking and their perceptions of practicing critical thinking in the classroom.

Teachers' definition of critical thinking. Most of the respondents, 15 out of 17 , defined critical thinking as the intellectual incentives which become the motivation to facilitate thinking among students in the classroom and enable students to enjoy the process of learning. They also defined this as a process that involves analysing information. The remaining 2 respondents explained that critical thinking involved logical reasoning and it plays a part in helping students think and analyse. Rather than just accepting the norm, solutions must be reasoned and justified. A substantial role is played by critical thinking. Students use critical thinking to analyse information and solve issues.

\section{DISCUSSION}

The findings show that respondents had two perspectives on critical thinking. Critical thinking, according to the majority of them, is a way of thinking that will assist pupils appreciate the learning process. This means that critical thinking may be used to help students think more critically and achieve better learning results. Critical thinking, according to the other respondents, entails reasoning that aids pupils in analysing their learning. However, none of the responders specified the level of learning they expected their pupils to achieve. The results seem to suggest that the respondents were more focused on students acquiring knowledge and learning to reason and analyse rather than reflecting and making appraisals of the material they learn.

It is interesting to note that none of the respondents used words like reflection or appraisal in their definition of critical thinking, words which Riddell (2007) noted are important components of critical thinking apart from ability to analyse and reason. Although acquiring knowledge and learning to reason and evaluate is important, it should not surpass the need for higher level cognitive thinking, that is, critical thinking which encompasses analysis, synthesis, and evaluation as noted in Bloom's definition of critical thinking (Dunn et al., 2006).

\section{Teachers' perceptions of practicing critical thinking} in their classroom.

All 17 of the respondents were certain that practicing critical thinking in their classrooms carries positive results. They also perceived that through critical thinking, students would be able to gain in-depth understanding of the subjects they were learning and apply what they have learned in real life. This process according to the respondents, make the most of the outcome of the students' learning experience as they would be able to achieve better results in their courses and perform better in class as well as becoming pro- 
active learners and independent thinkers.

Fifteen of the respondents added that students needed to be taught critical thinking in order to enhance their learning experience.

Consequently, all the respondents perceived that it was important that critical thinking happened in the classroom. They also perceived that critical thinking needed to be taught in order to help students perform better in class. These findings support arguments by Duron et al. (2006), Black (2005), Choy (2003), and Nickerson (1994) that students need to be taught critical thinking in order to help them to think and learn better.

Discussion.

Based on the findings, it appears that the majority of respondents believe critical thinking is an important part of the learning process. However, none of the respondents offered a clear definition of critical thinking beyond the fact that it entails analysis and reasoning. As noted by Ridell (2007) and Duron et al. (2006), critical thinking involves higher level thinking skills and involves complex processing of information. Critical thinking appears to be emphasized by the respondents as a technique for pupils to learn more effectively and apply what they have learnt in later life. None of the participants indicated that critical thinking entails higher-order thinking such as reflection and appraisal. Critical thinking should be encouraged in the classroom, according to all of the respondents.

\section{Research Question 2.}

What are Teachers' Perceptions of Students' Ability to Think Critically?

The results got from two categories: (a) teachers' perceptions of students' demonstration of critical thinking in their classroom and (b) their perceptions of the problem faced by students practicing critical thinking were used to answer RQ 2.

Teachers' perception of students' demonstration of critical thinking in their classrooms.

A total of 13 teachers perceive that their students do practice critical thinking in their classrooms some of the time.

Four of the respondents added that they knew that their students were practicing critical thinking when they were able to protect their arguments and problem solve using new approaches. They felt it was imperative for teachers to guide them and help mediate their learning. Discussion. Most of the respondents perceived that students demonstrated critical thinking when they were able to perceive facts thoughts and ideas from a new perspective and defend these ideas with sound argument. These students do not seem to reflect the skills that Riddell (2007) and Duron et al. (2006) argued are necessary to demonstrate critical thinking. According to these researchers, it is vital to have skills like reflection, inquiry, interpretation, and analysis. Based on this research, the results of the analysis do not seem to show that these students had been able to acquire all the skills necessary for critical thinking, although their teachers perceive they are demonstrating this type of thinking. This would imply that the level of critical thinking demonstrated by students would be dependent on how well their teachers understand the necessary skills for this type of thinking. Black (2005) suggested that teachers themselves may not even know how to think critically and, therefore, their analysis of the level of critical thinking among students may be limited by their own ability of thinking critically. Added to this, teachers may confuse students by telling them that expressing facts they were given in their own words was critical thinking, a point emphasized by Williams and Burden (1997) in their research into learning.

According to Williams and Burden, many teachers do not make a discrepancy between whether they are disseminators of information or a mediator of learning for an individual. Information disseminators are simply concerned in providing information to pupils, whereas learning mediators are engaged in assisting students in learning on their own. According to the respondents' remarks, they believed their pupils were capable of critical thinking when they were able to put what they had learned into their own words. These kids may not understand how to think critically because they equate rephrasing with critical thinking.

Teachers' perception of the problems faced by students when required to practice critical thinking in the classroom.

Students lack the ability to practice critical thinking, according to seventeen respondents. Because they were never taught or exposed to critical thinking as a talent in their early schooling, the pupils are ignorant of it as a competence. For example, one of them stated, 
"Students are very docile because they have not been taught how to think critically since they were young." Because it is difficult for them to understand what critical thinking is and how to apply it to the job at hand, 14 respondents expressed worry that pupils in the classroom act passively. They also stated that their kids lacked the necessary language competence or confidence to exhibit critical thinking.

Discussion. It would seem that students were unaware that they needed to think critically as they were not exposed to this form of thinking and were often confused when they were encouraged to do so. The respondents perceived that the students were also not encouraged about the critical thinking process as they did not respond well when asked to think critically. This would suggest the importance of helping teachers understand the importance of incorporating critical thinking into their lessons consistently. This finding is supported by Lauer (2005), who noted that helping teachers teach students to think critically in the classroom can be a challenge. According to Lauer, techniques to teach critical thinking must be incorporated into the lessons so as to facilitate a smooth flow of the lesson at the same time teach critical thinking to students.

The finding that the respondents found their students passive and inhibited during discussion to enhance critical thinking could imply that students' and teachers' perceptions of the learning taking place in the classroom are very different. This supports the findings of Horwitz (1989), whereby the way teachers view their students would influence the learning that takes place in the classroom.

\section{Research Question 3.}

\section{What Are Their Perceptions of the Role They Have to Play When Incorporating Critical Thinking in Their Lessons?}

The results from two categories were used to answer RQ 3. The two categories are (a) teachers' views about ways of encouraging critical thinking in their lessons and (b) teachers' perception of the students' enjoyment of their classes as a contributing factor to critical thinking.

Teachers' views about ways of encouraging critical thinking in their lessons.
All of the respondents were confident that by giving students with rules and suggestions, they could integrate critical thinking in their classes. This would allow students to investigate and learn to think critically on their own. They also believed that playing the role of a mediator by giving students cues instead of notes, such as themes, keywords, and so on, would encourage them to exercise critical thinking more successfully. Instead, they might be given particular activities to encourage them to think creatively, such as role-playing where pupils are forced to solve problems using their own ideas, as one responder suggested.

We could also conduct group discussions that require students to air their views and come up with solutions. They could also be given texts to read and then answer questions which require them to think out of the box. Seventeen respondents added that it was important to encourage students to be creative as creativity is essential in critical thinking that requires them to produce original ideas. They also suggested that students should also be given the preference to choose the topics that they want to study as this would empower the students and, thus, promote critical thinking. It could also increase the students' interest and in-depth understanding of the subject and create sense of responsibility towards their studies.

In addition, 17 respondents wrote that the learning environment in the classroom plays an important part in encouraging critical thinking among the students. To facilitate critical thinking in the classroom the respondents perceived that teachers play an important part in providing a conducive learning environment. However, 13 respondents felt that students expect lecturers to give notes containing all the information that the students need to know in order to answer the questions in their assessments.

Fifteen of the respondents further expressed concern that teachers themselves may not have mastered critical thinking causing the students to not develop this form of thinking well.

Discussion. This finding suggests that respondents are certain they could implement critical thinking in their classroom. Many of them suggested students could be empowered to choose what they wanted to learn and encouraged to problem solve using their own approaches. However, this certainty that they could implement critical thinking in their classroom seemed 
to be checked by the respondents' perception that students were on the whole dependent on their teachers to provide them with all the relevant study materials. Their lack of ability to understand the required reading materials is perceived by teachers as deterrents to helping students develop critical thinking skills.

Added to this the respondents were also unsure that teachers could think critically themselves. These perceptions could also be a result of the way they perceived their students and themselves. These respondents may actually be disseminator information rather than mediators. They may not know how to stimulate their students to think critically because they may not actually know how to think critically themselves. This finding supports research by Williams and Burden (1997) that the way in which teachers manage their classroom environments influences the way in they interact with students and the way they learn. Furthermore, the confidence of a teacher and their self- efficacy and self-esteem could influence the way they influence their students' thinking.

Teachers' perception of the students' enjoyment of their classes as a contributing factor to critical thinking.

Seven of the responders were convinced that their pupils enjoyed their lessons. Critical thinking was also practiced in the classroom, according to these respondents. All of the responders were certain that their classes were enjoyable, citing the feedback forms that students filled out at the conclusion of the semester as proof. They also believed that their personal delight in teaching their classes contributed to the students' appreciation of the lessons.

Discussion. This finding seems to suggest that most teachers perceive that their lessons were enjoyable to students. They also felt that their own enjoyment of the classes they teach was also a good indicator. In addition, the students' own preparations for the material to be learned would contribute to their ability to think critically. It is important to take into consideration the arguments of Horwitz (1989) that a teacher's perceptions were not shared by their students. Their students may actually be looking at the same situation from vastly different perspectives. However, the results do not seem to support Horowitz's argument. These students seem to enjoy their class as evidenced from the comments from the students' feedback questionnaire.

\section{SECTION THREE}

\subsection{Teacher Perceptions of Learning}

According to Sainn and Ugwuegbu (1980), perception may be defined as "the process by which we extract meaningful information from physical stimulation. It is the way we interpret our sensations" (p. 90). Sainn et al highpoint three important about perception. Firstly, perception is not only dependent on the stimulus but is also determined by an individual's experience, intention, and social needs. Secondly, the perceiver is not passive and indifferent when perceiving something but is actively choosing information and forming hypotheses in order to decide what is actually taking place. Thirdly, perception is a higher intellectual process which helps an individual build up a model of his or her world in order to help anticipate future happenings and deal with them appropriately. Therefore, the physical stimulation from sensory receptors of an individual gives relatively limited information and cannot be interpreted unless there is additional information derived from past experiences and memory. Once the physical stimuli are appropriately interpreted, they will become the perceptions of an individual.

Many contend that the perceptions of teachers influence their activities in the classroom. Horwitz (1989), in her article about student perceptions and language learning, cautioned that it is important for teachers to reflect how their students perceive them in the classroom as this can conflict with personal philosophies and attitudes towards teaching. She further stresses that "we (teachers) think of our classrooms as 'communication-centred' or 'grammarfocused', as dominated by 'teacher talk', while our students are more likely to think of their course as 'hard' or 'easy' and of their instructors as 'strict' or 'lenient"' (p. 61). It appears that the view of teachers and pupils can be diametrically opposed. Teachers, for example, might be more oriented towards imparting the skills necessary for effectively learning, but students may be more interested in the grading 
practices of their teachers, due dates for assignments, and the number of projects they need to complete for the course. A similar view is shared by Lauer (2005) who posits that teacher may not know how to integrate critical thinking into their lessons. Teachers may find it a challenge to teach students critical thinking, as it is sometimes problematic to incorporate aspects of critical thinking into their lessons.

It must be noted that there is a variance between whether teachers perceive themselves as disseminators of information or a mediator of learning for an individual. As noted by Williams and Burden (1997), a mediator allows an individual to learn by teaching the relevant skills and strategies to learn. There is also interaction between the learner and teacher and the learner is an active participant of the learning process The student is able to express his or her thoughts to the teacher and is willing to complete the assignment. Teachers who see themselves as knowledge disseminators, on the other hand, pay little attention to student input and feedback. The teacher has complete control over the classroom, and pupils' ability to learn is in doubt. As a result, it's debatable whether a pupil can learn critical thinking abilities from such an instructor.

\subsection{Challenges that face educators in}

\section{implementing critical thinking strategies}

Snyder and Snyder (2008) identify lack of training and information among educators; personal beliefs and preconceptions; and time constraints as challenges that may limit teachers to effective teaching of critical thinking in their classrooms. However, I did not witness the mentioned obstacles in reality throughout my teaching practice experience at my practicing school. Time constraints were not an issue since, as I saw, 60 minutes of teaching time was adequate to engage students in various teaching and learning activities such as group discussion, watching video clips, and completing subject-related reflections.

The big challenge observed in Norwegian schools was the issue of handling adolescent learners. The 21 st century classrooms should promote a learner at the centre of learning while the role of the teacher remains that of facilitating learning among learners. However, my teaching practice experiences revealed deviant learning behaviours among learners whereby at school, sometimes students were not motivated to learn and feel engaged, and instead some students could move outside the classroom while the session was in progress, and also, others students were busy doing other things different from what the teacher required them to do. In actual sense, I have learnt that, handling adolescent students' behaviours is very challenging especially in a situation where students are more autonomous and education system does not allow the use of punishment to misbehaving students like in Norway. In such instances, teachers must exercise great patience in order to ensure that all pupils learn. Apparently, when it comes to the problems of integrating critical education in Tanzanian contexts, all I can say is that we encounter just as many obstacles as Norwegian schools do. This is due to the fact that they are two distinct countries with a wide range of economic, social, cultural, political, and technical characteristics.

Despite the fact that ancient and modern theories have given a foundation for teaching critical thinking, many Tanzanian institutions, particularly public schools, continue to graduate students who lack the necessary problem-solving and analytical skills. This might be attributed to a number of variables, including large class numbers, instructors' lack of critical thinking expertise, students' poor information-searching abilities, and teachers' inclination for more behaviorist rather than constructivist teaching methods. Also, teachers' motivation is a pre-requisite for promoting critical thinking teaching for classroom instruction is lacking among many Tanzanian teachers. Demotivation among teachers has been due to long time experiences of low and irregular salary payments, lack of proper housing, inadequate facilities, low status accorded to them and limited opportunities for professional development.

Another challenge which constrains effective implementation of critical teaching in Iraq is the lack of required skills on how to use the modern technology. This is the problem of technical "know how' for teachers and is affecting the ability to use the teaching and learning materials, and besides that, Tanzania secondary schools lack sufficient teaching and learning materials. Most of the schools particularly government schools do not have relevant 
and adequate teaching learning materials in both science and arts subjects. For stance most of the schools do not have libraries, subject rooms like

\subsection{Conclusion}

Teachers believe they are teaching critical thinking to their pupils, according to the findings. They believe that critical thinking will give intellectual stimulation to pupils, allowing them to learn more effectively. They believe that pupils' capacity to describe topics in their own terms demonstrates critical thinking. However, this image is debatable because logical reasoning and the ability to solve problems using novel ways may not be indicative of critical thinking, but rather the process through which a student acquires comprehension of the information provided.. As Black (2005) aptly noted, critical thinking requires students to take their own thinking apart: to analyse their own thinking according to standards of clarity, accuracy, relevance, logic, and fairness. This seems to imply that teachers themselves may not have a strong understanding of critical thinking and how to encourage students to think in this way. This lack of understanding of the concept is also reflected in their definition of critical thinking. Many of them equate critical thinking to intellectual stimuli, but they are unable to define the forms these stimuli must take. Vaske (2001) noted that the definition of critical thinking needs to encompass both the natural qualities of a person - disposition - and the critical thinking skills of the person. This would imply that critical thinking can only be taught by teachers who have in- depth knowledge of critical thinking skills and understanding of how to incorporate this into their lessons so that it is easier for students to adapt to this type of thinking.

The conclusions also suggest that teachers are not confident that their students could learn to think critically on their own. Many of them perceive their students to be unwilling to share and lack the command of language to express their thoughts well. Black (2005) suggested that a climate of high expectations and teacher warmth that encouraged students to express their thoughts needed to be present to ensure success of critical thinking in the classroom. The tendency for teachers to provide the necessary materials and the need to complete their syllabi was indicative that they were not able to incorporate critical thinking into their lessons all the time.

Numerous teachers also perceive that their students do not enjoy classes when discussions required them to think critically. The teachers also seem to be in struggle with wanting to stimulate critical thinking in their students and needing to complete the stipulated requirements of the course. This is a dilemma because the relevant governing and licensing bodies of these institutions may not be aware of the needs and the time constraints imposed on teachers. Duron et al. (2006) noted that although content delivery is very important in higher education, it often does not encourage active learning of critical thinking among students. This tendency for teachers to provide all necessary learning materials and the need to complete syllabuses would imply a very structured approach to teaching.

The findings suggest that instructors' grasp of the notion of critical thinking has to develop in order for them to effectively educate students to think critically. There also appears to be a misunderstanding of the prerequisites for teaching pupils to think critically. Many teachers believe they are assisting students in developing critical thinking skills, but they may instead be focused on their understanding of the topic matter. Before attempting to include critical thinking into their classes, teachers should evaluate their existing educational techniques as well as their own views. Critical thinking is a learning process that needs to be constantly practiced and incorporated into daily lessons. With the current constraints and requirements of the teachers, the success of this process is questionable. Further studies need to be carried out on how teachers perceive meeting expected requirements and time constraints could be hindering them from effectively incorporating critical thinking into their lessons. 


\section{REFERENCES}

[1] Al Khanaifsawy, A. N. (2017). A STYLISTIC STUDY OF EUPHEMISM IN JOHN DONNE'S SELECTED POEMS. The Islamic University College Journal, 35-38.

[2] Al Khanaifsawy, A. N. (2019). A SOCIO-PRAGMATIC STUDY OF OFFER STRATEGIES MANIPULATED BY IRAQI DIALECT SPEAKERS. The Islamic college university journal. Vol (8), No. (II).

[3] Al-Khanaifsawy, A. N. (2016). Investigating Iraqi EFL learners' use of the speech act of agreement. Adab Al-Kufa,1(27), 11-30.

[4] Black, S. (2005). Teaching students to think critically. The Education Digest, 70(6), 42-47.

[5] Bushra Alnoori. ( 2019). Impact of Teaching Grammar through activities to Iraqi EFL Pupils and Attitude of Teachers Towards Activities. Transylvanian Review (XXVII ( 42), 1221-1249.

[6] Bushra Saadoon Al- Noori. (2019). TEACHING ENGLiSH THROUGH HUMOR AND JOKES). International Journal of Advancement in Social Science and Humanity. Vol. No. 8. Jul-Dec.

[7] Bushra Saadoon Mohammed Alnoori. (2019). IMPACT OF TEACHING GRAMMAR THROUGH ACTIVITIES TO IRAQI EFL PUPILS AND ATTITUDE OF TEACHERS TOWARDS ACTIVITIES. Transylvanian Review.Vol XXVII, No. 42.

[8] Bushra Saadoon Mohammed Alnoori.(2019). Writing skills developed through Language Integrated Content. Artículo de investigación Vol. 8 Núm. 19/Marzo - abril.

[9] Choy, S. C. (2003). An investigation into the changes in perceptions of and attitudes towards learning English in a Malaysian college. Unpublished doctoral thesis, University of Exeter, Exeter, U.K.

[10] Denzin, N. K., \& Lincoln, Y. S. (Eds.). (1994). Handbook of qualitative research. Thousand Oaks, CA: Sage.

[11]Duron, R., Limbach, B., \& Waugh, W. (2006). Critical thinking framework for any discipline. International Journal of Teaching and Learning in Higher Education, 17(2), 160-166.

[12] Greene, J. C. (2000). Qualitative program evaluation: practice and promise. In N. K. Denzin \& Y. S. Lincoln (Eds.), Handbook of qualitative research. Thousand Oaks, CA: Sage.

[13] Holliday, A. R. (2002). Doing and writing qualitative research. London: Sage.

[14] Horwitz, E. K. (1989). Facing the blackboard:

[15] Lauer, T. (2005). Teaching critical-thinking skills using course content material. Journal of College Science Teaching, 34(6), 34-44.

[16] Nickerson, R. S. (1994). The teaching of thinking and problem solving. In R. J. Sternberg (Ed.), Thinking and problem solving (pp. 121-132). San Diego: Academic Press.

[17] Radnor, H. A. (2002). Researching your professional practice: Doing interpretive research. London: Open University Press.

[18] Rafal Lateef Jasim \& Bushra Saadoon Mohammed AL-Noori. (2020). THE EFFECT OF LS APPROACH

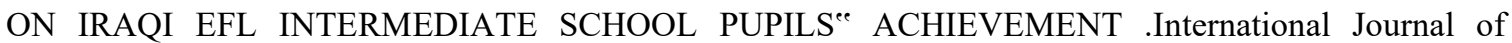
Advancement in Social Science and Humanity. Vol. No. 10, Issue No. III, Jul-Sep.

[19] Riddell, T. (2007). Critical assumptions: Thinking critically about critical thinking. Journal of Nursing Education, 46(3), 121-126.

[20] Sainn, G., \& Ugwuegbu, D. C. E. (1980). Education psychology in a changing world. London: UnwinHyman.

[21] Schultz, R. A. (2001). Cultural difference in student and teacher perceptions concerning the role of grammar instruction and corrective feedback. The Modern Language Journal, 85(2), 244-258.

[22] Sternberg, R. J., \& Williams, W. M. (2002). Educational psychology. Boston: Allyn and Bacon. Vaske, J. M. (2001). Critical thinking in adult education: An elusive quest for a definition of the field 
[23] Student perceptions of language learning and the language classroom. ADFL Bulletin, 20(3), 61-64.

[24] University, Des Moines, Iowa.

[25] Urooba Issa Yasseen \& Bushra Saadoon Mohammed AL-Noori. (2019). EVALUATING IRAQI EFL INTERMEDIATE SCHOOL COURSE BOOKS "ENGLISH FOR IRAQ" FROM TEACHERS' AND PUPILS' POINT OF VIEW. International Journal of Advancement in Social Science and Humanity. Vol. No. 9, Issue No. IV, Oct-Dec.

[26] Williams, M., \& Burden, R. L. (1997). Psychology for language teachers. Cambridge, United Kingdom: Cambridge University Press.

\section{Appendix 1}

\section{List of Questions on the Questionnaire on Teacher's Perceptions of Critical Thinking}

1. From your viewpoint, what is critical thinking?

2. What role, in your opinion, does critical thinking play in your classroom?

3. Do you think that critical thinking happens in your classroom when you are teaching your students? If so, how do you know?

4. How do you think you could bring about critical thinking among students? Specifically, what are some things you do or could do to get your students to think critically?

5. What are the problems faced by students when you are trying to teach them critical thinking? If so identify them.

6. Do you think your lessons are enjoyable to students? Why and why not?

7. Do you think you need to give all the information to your students in order for them to learn your subject? Why and why not?

8. Do you think you would be able to implement critical thinking into your lessons if you were required to do so? Why and why not? 